\title{
Columns, Spinal et al.
}

\author{
J.M.S. Pearce \\ Emeritus Consultant Neurologist, Department of Neurology, Hull Royal Infirmary, Hull, UK
}

We are all familiar with columns, not just the arrangements of text or tables on pages written by columnists, or the Doric, Ionic and Corinthian constructions so beloved of the ancient Greeks, but in many anatomical terms. The Latin columna was a collateral form of columen, culmen - an elevated object, pillar or column. It comes from $\mathrm{cel}$, whence celsus 'high' or 'lofty', as found in celestial, i.e. heavenly.

An architectural column was a round pillar with base, shaft, and capital supporting a building's architrave or freeze. In Gothic and Norman architecture it was a pillar for supporting the arch, but sometimes standing alone as a monument, e.g. Trajan's Column in Rome or Nelson's Column in London.

As medical students, we quickly encountered 'columnar epithelium' - simple, ciliated or glandular. It first appears in this adjectival form in 1845 in Todd \& Bowman's Physiological Anatomy and Physiology of Man (vol. II, p. 3): 'The epithelium being of the columnar variety, and clothed with cilia.'

Then we learned about the columnar arrangements of the cortical mantle of the brain. Other examples are the fleshy columns of the heart called columnoe carnea; the anterior part of the nasal septum named columna nasi, and the spinal or vertebral column. In human anatomy it first appeared in 1831, in R. Knox's edition of Cloquet's Anatomy, as: 'Before the vertebral column'; Lockhart Clarke used the word to describe his 'posterior vesicular column' now known as Clarke's column of grey matter [1]. And, in Thomas Huxley's Lessons in Elementary Physiology, 1872, is found: 'Along the spinal column the spinal nerves give off branches.'
Column has been used botanically since the 17 th century. William Withering, who discovered the use of digitalis in dropsy (oedema), used it thus in 1776 (A Botanical Arrangement of British Plants, vol II, p. 824): 'A capsule cut open horizontally to shew ... the column in the centre, to which the partitions are connected.'

A bacterial disease of freshwater fish caused by Chondrococcus columnaris, forms short column-shaped masses on the edges of the infected tissues or scales. Geologists apply the word to rocks such as basalt and crystals, which have a column-like structure.

Poets have also used columns descriptively and figuratively: Lord Byron in Childe Harold's Pilgrimage (1812) I 54, refers to 'The column-scattering bay'net' [bayonet].

Truly a word of many parts.

Reference 1 Clarke JAL: Researches into the structure of the Spinal Chord [1850]. Philos Trans Roy Soc London 1851;141:607-822.

\section{KARGER}

Fax +4161306 1234 E-Mail karger@karger.ch www.karger.com
(C) 2006 S. Karger AG, Basel 0014-3022/06/0553-0181\$23.50/0

Accessible online at: www.karger.com/ene
J.M.S. Pearce

304 Beverley Road

Anlaby, East Yorks HU10 7BG (UK) 